\title{
Gold based bulk metallic glass
}

\author{
Jan Schroers ${ }^{\text {a) }}$ \\ Keck Laboratory of Engineering Materials, California Institute of Technology, Pasadena, \\ California 91125 and Liquidmetal Technologies, Lake Forest, California 92630
}

Boonrat Lohwongwatana and William L. Johnson

Keck Laboratory of Engineering Materials, California Institute of Technology, Pasadena, California 91125

\author{
Atakan Peker \\ Liquidmetal Technologies, Lake Forest, California 92630
}

(Received 7 February 2005; accepted 2 June 2005; published online 3 August 2005)

\begin{abstract}
Gold-based bulk metallic glass alloys based on $\mathrm{Au}-\mathrm{Cu}-\mathrm{Si}$ are introduced. The alloys exhibit a gold content comparable to 18-karat gold. They show very low liquidus temperature, large supercooled liquid region, and good processibility. The maximum casting thickness exceeds $5 \mathrm{~mm}$ in the best glassformer. $\mathrm{Au}_{49} \mathrm{Ag}_{5.5} \mathrm{Pd}_{2.3} \mathrm{Cu}_{26.9} \mathrm{Si}_{16.3}$ has a liquidus temperature of $644 \mathrm{~K}$, a glass transition temperature of $401 \mathrm{~K}$, and a supercooled liquid region of $58 \mathrm{~K}$. The Vickers hardness of the alloys in this system is $\sim 350 \mathrm{Hv}$, twice that of conventional 18-karat crystalline gold alloys. This combination of properties makes the alloys attractive for many applications including electronic, medical, dental, surface coating, and jewelry. (C) 2005 American Institute of Physics.
\end{abstract}

[DOI: $10.1063 / 1.2008374]$

Gold became known to mankind thousands years ago, and has been of inestimable value to civilization ever since. It is the noblest of the noble metals, and has a good combination of high thermal conductivity, high electrical conductivity, and high corrosion resistance. These properties have resulted in extensive use of gold and its alloys in electronic, aerospace, astronomy, medical, and industrial applications. For instance, gold can be found in many of today's sophisticated electronic devices. However, gold has always been most valued as a jewelry material. Gold alloys are easy to fashion, are nonallergenic, have a bright pleasing color, and remain tarnish free indefinitely. Pure gold and higher karat gold alloys, however, are rather soft and therefore vulnerable to wear and scratching. This results in diminished aesthetic appearance, and is a drawback of conventional crystalline gold alloys.

In the last two decades, several alloys based on $\mathrm{Pd},{ }^{1-3}$ $\mathrm{La},{ }^{4} \mathrm{Zr},{ }^{5,6} \mathrm{Fe},{ }^{7-9}$ and $\mathrm{Pt}^{10}$ were found to form bulk amorphous phases. Fully amorphous samples are obtained when the alloys are cast into copper molds of diameter up to centimeters which indicates critical cooling rates for glass formation of $100 \mathrm{~K} / \mathrm{s}$ or less. These bulk metallic glasses (BMGs) exhibit properties such as high strength, large elastic strain limit, high hardness, and, in some cases, substantial ductility. ${ }^{11}$ The compositions of these BMGs are typically close to a deep eutectic composition. Consequently, their melting temperatures are much lower than estimated from interpolation of the alloy constituents' melting temperatures. The resulting low liquidus temperature is an attractive property for casting alloys. The extraordinary stability of BMG forming alloys against crystallization also results in a large supercooled liquid region, $\Delta T,\left(\Delta T=T_{x}-T_{g}, T_{x}\right.$ : crystallization temperature, $T_{g}$ : glass transition temperature), the temperature region in which the amorphous phase first relaxes into a highly viscous liquid before eventually crystallizing.

${ }^{\text {a)} E l e c t r o n i c ~ m a i l: ~ j a n . s c h r o e r s @ ~ @ i q u i d m e t a l . c o m ~}$
In this temperature region, BMG's are amenable to superplastic processing using netshape processing methods similar to those employed for thermoplastics. ${ }^{12}$

The binary gold silicon eutectic composition was the first alloy found to exhibit metallic glass formation by Duwez and co-workers in $1960 .^{13}$ The critical cooling rate for glass formation of this alloy is of the order of $10^{6} \mathrm{~K} / \mathrm{s}$, resulting in a critical casting thickness, $d_{\mathrm{c}}$, below 50 microns. In an effort to increase the glass forming ability of this alloy, $\mathrm{Si}$ was partially replaced by $\mathrm{Ge}$, which resulted in only moderate increase of the glass forming ability and the width of the supercooled liquid region. ${ }^{14,15}$ The poor glassforming ability of these early metallic glasses and the low glass transition temperature make these alloys of marginal interest for most applications and explains the limited interest in these Au-based metallic glasses over the past several decades.

A suitable amorphous gold based alloy for applications such as jewelry, electronics, or dental reguires a $T_{g}$ of at least $370 \mathrm{~K}$ to be stable at ambient temperatures. Other desirable properties include: a large gold content $(\sim 18$ karat or higher), high hardness, good processibility, and a critical casting thickness that permits fabrication of net shaped articles such as jewelry. From a processing point of view, it is desirable to possess a large supercooled liquid region which gives access to a low forming viscosity, which in turn facilitates superplastic forming.

In this letter we report gold based bulk metallic glass forming compositions of various complexities, with a gold content comparable to 18-karat gold alloys. Samples were prepared by alloying the elements (Au: $99.95 \%, \mathrm{Cu}: 99.9 \%$, Ag: $99.5 \%$, Pd: $99.95 \%$, Si: $99.95 \%$ purity) in an arc-melter. Copper mold quenching was performed to solidify the alloy in its amorphous state, and to determine the critical casting thickness. Thermal analysis was performed in a differential scanning calorimeter (DSC) Netzsch DSC 404c. X-ray diffraction (XRD) was carried out on an Inel XRG 3000 using 


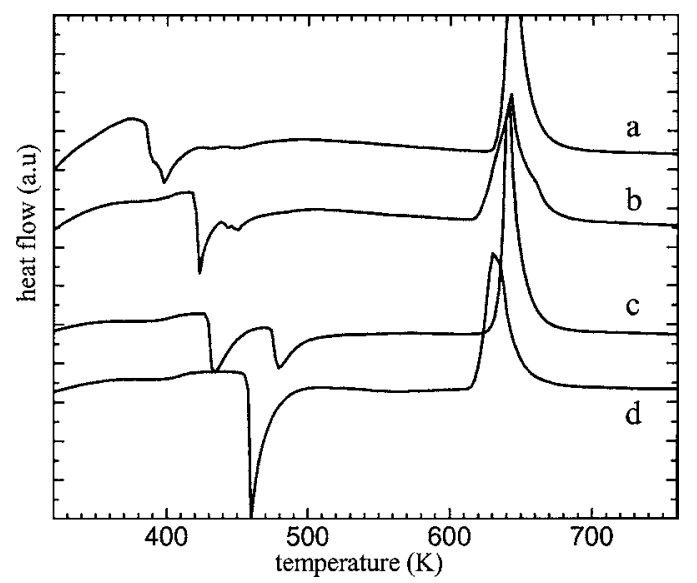

FIG. 1. DSC thermogram determined by heating with $20 \mathrm{~K} / \mathrm{min}$ of gold based alloys of various compositions that were cast in copper molds of various sizes. (a) $\mathrm{Au}_{55} \mathrm{Cu}_{25} \mathrm{Si}_{20}$ cast in $0.5 \mathrm{~mm}$ copper mold; (b) $\mathrm{Au}_{46} \mathrm{Ag}_{5} \mathrm{Cu}_{29} \mathrm{Si}_{20}$ cast in $1 \mathrm{~mm}$ copper mold; (c) $\mathrm{Au}_{52} \mathrm{Pd}_{2.3} \mathrm{Cu}_{29.2} \mathrm{Si}_{16.5}$ cast in $2 \mathrm{~mm}$ copper mold; (d) $\mathrm{Au}_{49} \mathrm{Ag}_{5.5} \mathrm{Pd}_{2.3} \mathrm{Cu}_{26.9} \mathrm{Si}_{16.3}$ cast in $5 \mathrm{~mm}$ copper mold.

$\mathrm{Cu} K \alpha$ radiation. Hardness tests were performed on a Leco R-600.

Within this alloy development work a large number of compositions was studied from various families of alloys. The alloys that are explicitly introduced represents the compositions in each alloy family with the highest glass forming ability. Figure 1 shows the DSC thermogram obtained by heating at a rate of $20 \mathrm{~K} / \mathrm{min}$ for four gold alloys. The thermogram in Fig. 1(a) is that of $\mathrm{Au}_{55} \mathrm{Cu}_{25} \mathrm{Si}_{20}$ which was cast in a $0.5 \mathrm{~mm}$ copper mold, Fig. 1(b) shows $\mathrm{Au}_{46} \mathrm{Ag}_{5} \mathrm{Cu}_{29} \mathrm{Si}_{20}$, cast at $1 \mathrm{~mm}$, Fig. 1(c) shows $\mathrm{Au}_{52} \mathrm{Pd}_{2.3} \mathrm{Cu}_{29.2} \mathrm{Si}_{16.5}$ cast at $2 \mathrm{~mm}$, and Fig. 1(d) shows $\mathrm{Au}_{49} \mathrm{Ag}_{5.5} \mathrm{Pd}_{2.3} \mathrm{Cu}_{26.9} \mathrm{Si}_{16.3}$ cast at $5 \mathrm{~mm}$. All compositions are in atomic percent. All alloys show a glass transition and a crystallization peak suggesting that at least some fraction of the material was amorphous. A comparison of the heat of crystallization, $\Delta H$, and the heat of fusion, $H_{f}$, which are summarized for the various alloys in Table I gives approximately $\Delta H / H_{f}=0.6$, a value typical for an entirely amorphous sample. When comparing with the $T_{\mathrm{g}}$ of the early gold alloys of about $300 \mathrm{~K}$ (Refs. 13-15) all alloys have surprisingly high $T_{g}$. Their $T_{g}$ is higher than $370 \mathrm{~K}$ with the exception of $\mathrm{Au}_{55} \mathrm{Cu}_{25} \mathrm{Si}_{20}$, thereby exceeding requirements for most jewelry applications.

Figure 2 shows the $\mathrm{x}$-ray diffractogram of the four alloys. The diffractogram in Fig. 2(a) is that of $\mathrm{Au}_{55} \mathrm{Cu}_{25} \mathrm{Si}_{20}$ cast in a $0.5 \mathrm{~mm}$ copper mold, Fig. 2(b) shows $\mathrm{Au}_{56} \mathrm{Ag}_{5} \mathrm{Cu}_{29} \mathrm{Si}_{20}$ cast at $1 \mathrm{~mm}$, Fig. 2(c) shows $\mathrm{Au}_{52} \mathrm{Pd}_{2.3} \mathrm{Cu}_{29.2} \mathrm{Si}_{16.5}$ cast at $2 \mathrm{~mm}$, and Fig. 2(d) shows $\mathrm{Au}_{49} \mathrm{Ag}_{5.5} \mathrm{Pd}_{2.3} \mathrm{Cu}_{26.9} \mathrm{Si}_{16.3}$ cast at $5 \mathrm{~mm}$. All spectra show

TABLE I. Summary of the properties of the various gold based alloys. The maximum thickness the alloy could be cast amorphous, $d_{c}$, was determined for copper mold quenching.

\begin{tabular}{lcccccccc}
\hline \hline \multicolumn{1}{c}{$\begin{array}{c}\text { Composition } \\
(\text { at \% })\end{array}$} & $\begin{array}{c}T_{g} \\
(\mathrm{~K})\end{array}$ & $\begin{array}{c}T_{x} \\
(\mathrm{~K})\end{array}$ & $\begin{array}{c}\Delta T \\
(\mathrm{~K})\end{array}$ & $\begin{array}{c}T_{l} \\
(\mathrm{~K})\end{array}$ & $\begin{array}{c}T \mathrm{rg} \\
T_{g} / T_{l}\end{array}$ & $\begin{array}{c}d_{c} \\
(\mathrm{~mm})\end{array}$ & $\begin{array}{c}\Delta H \\
(\mathrm{~J} / \mathrm{g})\end{array}$ & $\begin{array}{c}H_{f} \\
(\mathrm{~J} / \mathrm{g})\end{array}$ \\
\hline $\mathrm{Au}_{49} \mathrm{Ag}_{5.5} \mathrm{Pd}_{2.3} \mathrm{Cu}_{26.9} \mathrm{Si}_{16.3}$ & 401 & 459 & 58 & 644 & 0.62 & 5 & 35 & 46 \\
$\mathrm{Au}_{52} \mathrm{Pd}_{2.3} \mathrm{Cu}_{29.2} \mathrm{Si}_{16.5}$ & 393 & 427 & 34 & 651 & 0.6 & 2 & 33 & 49 \\
$\mathrm{Au}_{46} \mathrm{Ag}_{5} \mathrm{Cu}_{29} \mathrm{Si}_{20}$ & 395 & 420 & 25 & 664 & 0.59 & 1 & 28 & 46 \\
$\mathrm{Au}_{55} \mathrm{Cu}_{25} \mathrm{Si}_{20}$ & 348 & 383 & 35 & 654 & 0.53 & 0.5 & 32 & 57 \\
\hline
\end{tabular}

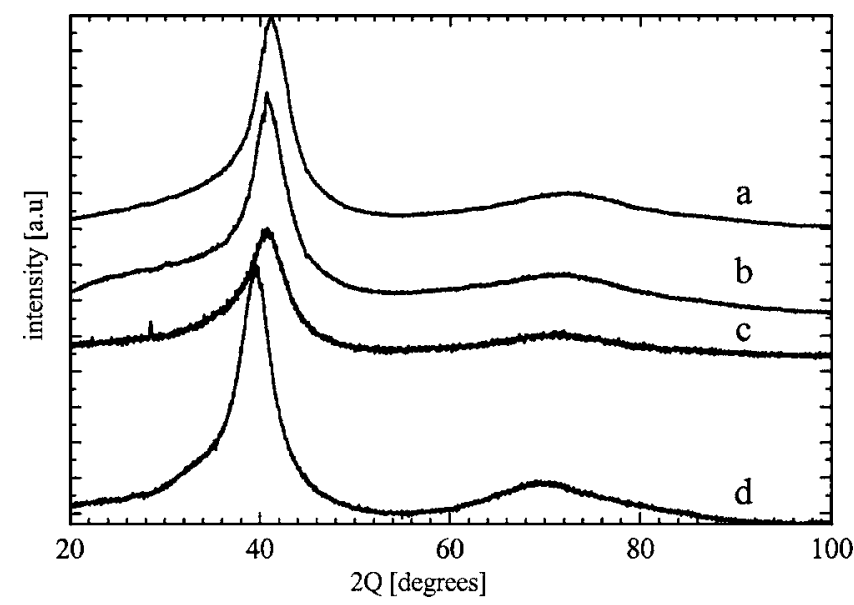

FIG. 2. X-ray diffraction thermogram of gold based alloys of various compositions that were cast in copper molds with various diameters. (a) $\mathrm{Au}_{55} \mathrm{Cu}_{25} \mathrm{Si}_{20}$ cast in $0.5 \mathrm{~mm}$ copper mold; (b) $\mathrm{Au}_{46} \mathrm{Ag}_{5} \mathrm{Cu}_{29} \mathrm{Si}_{20}$ cast in $1 \mathrm{~mm}$ copper mold; (c) $\mathrm{Au}_{52} \mathrm{Pd}_{2.3} \mathrm{Cu}_{29.2} \mathrm{Si}_{16.5}$ cast in $2 \mathrm{~mm}$ copper mold; (d) $\mathrm{Au}_{49} \mathrm{Ag}_{5.5} \mathrm{Pd}_{2.3} \mathrm{Cu}_{26.9} \mathrm{Si}_{16.3}$ cast in $5 \mathrm{~mm}$ copper mold.

broad maxima typical for entirely amorphous material, supporting the DSC results.

The results are summarized in Table I. All alloys show liquidus temperatures of below $700 \mathrm{~K}$. $\mathrm{Au}_{49} \mathrm{Ag}_{5.5} \mathrm{Pd}_{2.3} \mathrm{Cu}_{26.9} \mathrm{Si}_{16.3}$ has a liquidus temperature as low as $644 \mathrm{~K}$. With the glass transition temperature of $401 \mathrm{~K}$, the alloy has the reduced glass transition temperature, $T_{\mathrm{rg}}$ $=T_{g} / T_{l}$, of 0.62 , a value only seen among excellent bulk metallic glassformers. ${ }^{16}$ The supercooled liquid region for $\mathrm{Au}_{55} \mathrm{Cu}_{25} \mathrm{Si}_{20}, \mathrm{Au}_{56} \mathrm{Ag}_{5} \mathrm{Cu}_{29} \mathrm{Si}_{20}$, and $\mathrm{Au}_{52} \mathrm{Pd}_{2.3} \mathrm{Cu}_{29.2} \mathrm{Si}_{16.5}$ is approximately $30 \mathrm{~K}$. For $\mathrm{Au}_{49} \mathrm{Ag}_{5.5} \mathrm{Pd}_{2.3} \mathrm{Cu}_{26.9} \mathrm{Si}_{16.3}$, the supercooled liquid region reaches $58 \mathrm{~K}$.

$\Delta T$ is often used as a parameter that describes the super plastic formability of a BMG. ${ }^{17,18}$ However, when comparing the formability of different alloy systems, $\Delta T$ should be normalized to the width of the undercooled liquid region, $T_{l}$ $-T_{g}\left(T_{l}\right.$ : liquidus temperature). The parameter, $\mathrm{S}=\Delta T /\left(T_{l}\right.$ $-T_{g}$ ), shows better correlation with formability, even though the assumption of identical fragility of the liquid and viscosity at $T_{l}$ is oversimplified. ${ }^{19}$ The $S$ parameter for $\mathrm{Au}_{49} \mathrm{Ag}_{5.5} \mathrm{Pd}_{2.3} \mathrm{Cu}_{26.9} \mathrm{Si}_{16.3}$ of 0.24 exceeds even the one for $\mathrm{Zr}_{44} \mathrm{Ti}_{11} \mathrm{Cu}_{10} \mathrm{Ni}_{10} \mathrm{Be}_{25}$ of 0.2 , an alloy frequently used and known for its super plastic formability, ${ }^{20}$ but is below the

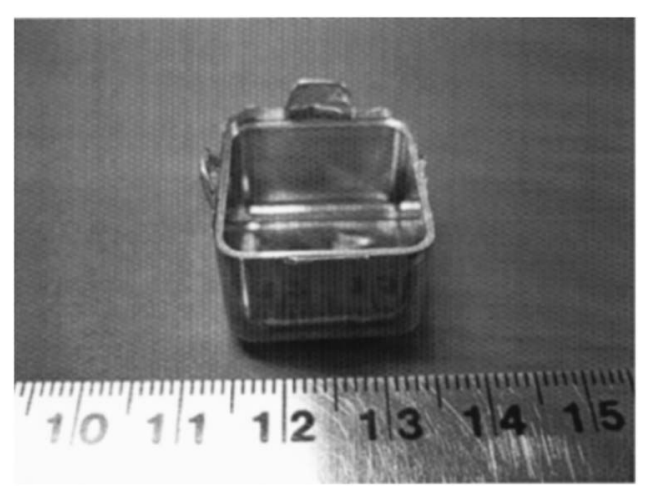

FIG. 3. $\mathrm{Au}_{49} \mathrm{Ag}_{5.5} \mathrm{Pd}_{2.3} \mathrm{Cu}_{26.9} \mathrm{Si}_{16.3}$, superplastically formed from a rod shape into this article. The forming was carried out in air at $423 \mathrm{~K}$ for $200 \mathrm{~s}$ under a forming pressure of $100 \mathrm{MPa}$. The amorphous structure of the plastically formed article was confirmed by DSC and $\mathrm{x}$ ray. Note that the as-formed article is shown with no subsequent finishing. The flash and overflows have not been removed. 

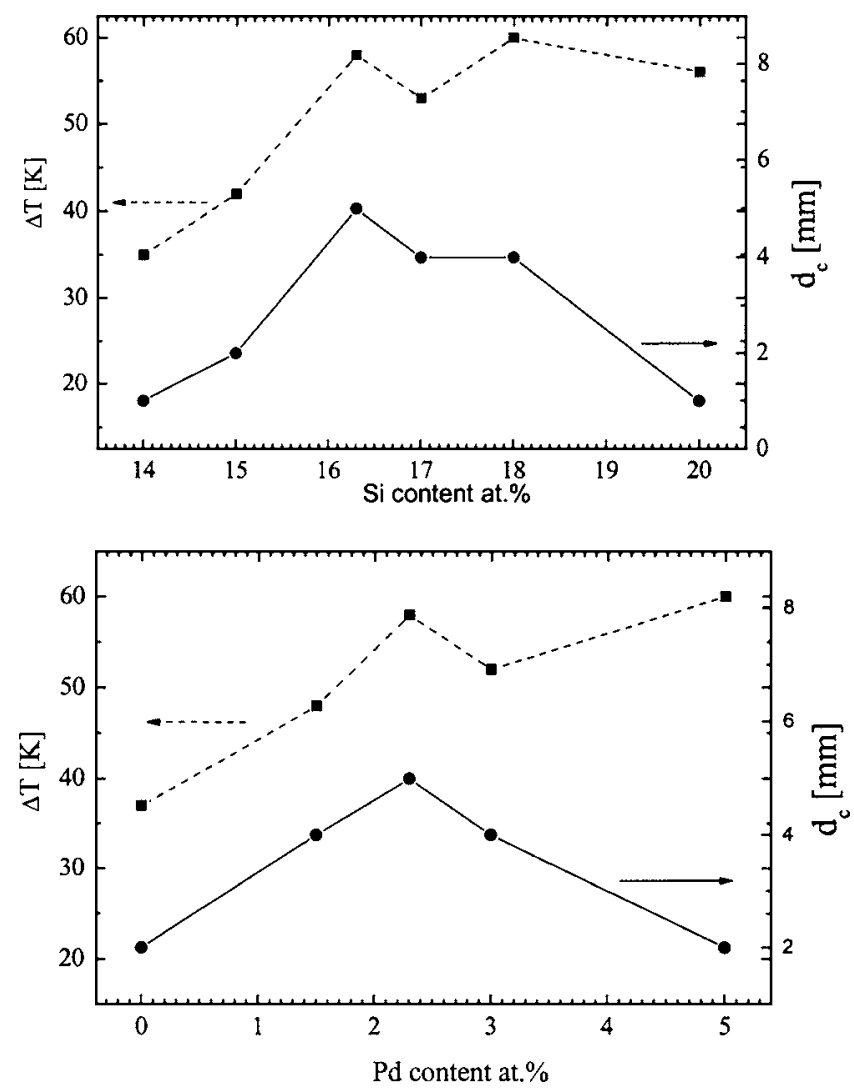

FIG. 4. Composition dependence of $\Delta T$ and $d_{c}$ for $\left(\mathrm{Au}_{58.5} \mathrm{Ag}_{6.6} \mathrm{Pd}_{2.8} \mathrm{Cu}_{32.1}\right)_{86-x} \mathrm{Si}_{14+x}$ for $\quad x=0-6 \quad$ (top); $\left(\mathrm{Au}_{60.1} \mathrm{Ag}_{6.8} \mathrm{Cu}_{33.1}\right)_{83.7-y} \mathrm{Pd}_{y} \mathrm{Si}_{16.3}$ for $y=0-5 \%$ (bottom). A strong dependence on the $\mathrm{Si}$ and Pd content of both, $d_{c}$ and $\Delta T$ is observed. No obvious correlation of $d_{c}$ and $\Delta T$ is seen.

parameter for $\mathrm{Pt}_{57.5} \mathrm{Cu}_{14.7} \mathrm{Ni}_{5.3} \mathrm{P}_{22.5}$ (Ref. 10) of $S=0.34$, the highest $S$ value among all bulk metallic glass forming alloys. The large $S$ parameter for $\mathrm{Au}_{49} \mathrm{Ag}_{5.5} \mathrm{Pd}_{2.3} \mathrm{Cu}_{26.9} \mathrm{Si}_{16.3}$ suggests good formability. Superplastic forming of $\mathrm{Au}_{49} \mathrm{Ag}_{5.5} \mathrm{Pd}_{2.3} \mathrm{Cu}_{26.9} \mathrm{Si}_{16.3}$ was demonstrated by forming rod shaped material into various geometries. Figure 3 shows an article that was formed in air at $423 \mathrm{~K}$ for $200 \mathrm{~s}$ using an applied pressure of $100 \mathrm{MPa}$. The amorphous structure of the plastically formed articles was confirmed by DSC and x-ray. The precise replication of the complex geometry confirms the excellent formability as suggested already by the $S$ parameter.

For the three bulk glassforming alloys, $\mathrm{Au}_{56} \mathrm{Ag}_{5} \mathrm{Cu}_{29} \mathrm{Si}_{20}, \quad \mathrm{Au}_{52} \mathrm{Pd}_{2.3} \mathrm{Cu}_{29.2} \mathrm{Si}_{16.5}, \quad$ and $\mathrm{Au}_{49} \mathrm{Ag}_{5.5} \mathrm{Pd}_{2.3} \mathrm{Cu}_{26.9} \mathrm{Si}_{16.3}$, Vickers hardness was determined to be approximately $360 \mathrm{Hv}$. This is an extraordinarily high value when compared with conventional 18-karat gold alloys which have Vickers hardness around $150-200 \mathrm{Hv} .{ }^{21}$ Ultrasonic measurements were carried out to determine the elastic constants of amorphous $\mathrm{Au}_{49} \mathrm{Ag}_{5.5} \mathrm{Pd}_{2.3} \mathrm{Cu}_{26.9} \mathrm{Si}_{16.3}$. Youngs modulus was determined to be $74.4 \mathrm{GPa}$, shear modulus to be $26.45 \mathrm{GPa}$, and bulk modulus to be $132.31 \mathrm{GPa}$ which results in Poisson ratio of 0.406 .

A larger composition range in the composition space around the four alloys was studied and characterized to de- termine the correlation of glass forming ability and $\Delta T$ with composition. As an example, during the development of the $\mathrm{Au}_{49} \mathrm{Ag}_{5.5} \mathrm{Pd}_{2.3} \mathrm{Cu}_{26.9} \mathrm{Si}_{16.3}$ alloy, the $\mathrm{Au}$ content was varied between $40 \%$ and $60 \%, \mathrm{Ag}$ content was varied from 0 to $20 \%, \mathrm{Pd}$ from 0 to $5 \%, \mathrm{Cu}$ from 0 to $35 \%$, and $\mathrm{Si}$ from $14 \%$ to $20 \%$. Among the constituents of these alloys, the $\mathrm{Si}$ and Pd content have the strongest influence on the glass forming ability and $\Delta T$. This is illustrated in Fig. 4 which shows the dependence of the critical casting thickness and $\Delta T$ on Si and Pd content. The Si content was varied between $14 \%$ and $20 \%$ resulting in a variation of $d_{c}$ from $1 \mathrm{~mm}$ to $5 \mathrm{~mm}$, and a variation of $\Delta T$ from $35 \mathrm{~K}$ to $60 \mathrm{~K}$. By varying the Pd content from 0 to $5 \%, \Delta T$ increases continuously with some scatter whereas $d_{c}$ reaches a maximum at $\mathrm{Pd}=2.3 \%$. In both cases, a strong dependence of $\Delta T$ and $d_{c}$ on the composition variations can be observed. However, no obvious correlation between $\Delta T$ and $d_{c}$, as previously reported to be positive $e^{22,23}$ or negative, ${ }^{20,24}$ was observed.

In conclusion, gold based bulk metallic glass forming alloys were developed with a weight content of $\sim 18$ karat gold. The alloys show low liquidus temperature, large supercooled liquid region, large maximum casting thickness and good processibility for both casting and thermoplastic processing in a similar manner like thermo plastics. The combination of these properties together with their high hardness and esthetical appearance make them ideal for jewelry, dental, medical, and electronic applications.

${ }^{1}$ H. W. Kui, A. L. Greer, and D. Turnbull, Appl. Phys. Lett. 45, 615 (1984). ${ }^{2}$ N. Nishiyama and A. Inoue, Mater. Trans., JIM 37, 1531 (1996).

${ }^{3}$ I.-R. Lu, G. Wilde, G. P. Görler, and R. Willnecker, J. Non-Cryst. Solids 250-252, 577 (1999).

${ }^{4}$ A. Inoue, H. Yamaguchi, T. Zhang, and T. Masumoto, Mater. Trans., JIM 31, 104 (1990).

${ }^{5}$ A. Inoue, T. Zhang, and T. Masumoto, Mater. Trans., JIM 31, 177 (1990).

${ }^{6}$ A. Peker and W. L. Johnson, Appl. Phys. Lett. 63, 2342 (1993).

${ }^{7}$ V. Ponnambalam, S. J. Poon, G. J. Shiftlet, V. M. Keppens, R. Taylor, and G. Petculescu, Appl. Phys. Lett. 83, 1131 (2003).

${ }^{8}$ V. Ponnambalam, S. J. Poon, and G. J. Shiftlet, J. Mater. Res. 19, 1320 (2004).

${ }^{9}$ Z. P. Lu, C. T. Liu, J. R. Thompson, and W. D. Porter, Phys. Rev. Lett. 92, 245503 (2004)

${ }^{10}$ J. Schroers and W. L. Johnson, Appl. Phys. Lett. 84, 3666 (2004).

${ }^{11}$ J. Schroers and W. L. Johnson, Phys. Rev. Lett. 93, 255506 (2004).

${ }^{12}$ J. Schroers, JOM 5, 34 (2005).

${ }^{13}$ W. Klement, R. H. Willens, and P. Duwez, Nature (London) 187, 869 (1960).

${ }^{14} \mathrm{H}$. S. Chen and D. Turnbull, Appl. Phys. Lett. 10, 284 (1967).

${ }^{15}$ H. S. Chen and D. Turnbull, J. Chem. Phys. 48, 2560 (1969).

${ }^{16}$ Z. P. Lu, H. Tan, Y. Li., and S. C. Ng, Scr. Mater. 42, 667 (2000).

${ }^{17}$ T. Zhang and A. Inoue, Mater. Trans., JIM 44, 1143 (2003).

${ }^{18}$ V. Ponnambalam, S. J. Poon, and G. J. Shiftlet, J. Mater. Res. 19, 3046 (2004).

${ }^{19}$ S. Mukherjee, Z. Zhou, J. Schroers, W. L. Johnson, and W. K. Rhim, Acta Mater. 52, 3689 (2004).

${ }^{20}$ T. A. Waniuk, J. Schroers, and W. L. Johnson, Appl. Phys. Lett. 78, 1213 (2001).

${ }^{21}$ Metals Handbook, 9th ed. (American Society for Metals, Metals Park, Ohio).

${ }^{22}$ A. Inoue, T. Zhang, and T. Masumoto, J. Non-Cryst. Solids 156, 473 (1993).

${ }^{23}$ T. D. Shen and R. B. Schwarz, Appl. Phys. Lett. 75, 49 (1999).

${ }^{24}$ Y. C. Kim, W. T. Kim, and D. H. Kim, Mater. Sci. Eng., A A375, 127 (2004). 